DOI: https://doi.org/10.31933/dijms.v2i5

Received: $8^{\text {th }}$ June 2021, Revised: $2^{\text {th }}$ June 2021, Publish: $6^{\text {th }}$ July 2021

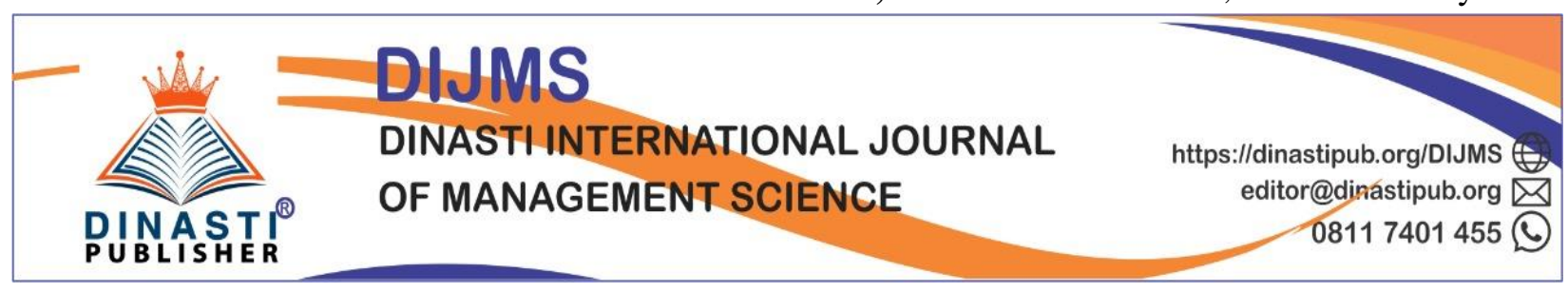

\title{
ANALYSIS OF THE INFLUENCE OF PRODUCT, PRICE, DISTRIBUTION, AND PROMOTION ON CONSUMER PURCHASE DECISIONS USING GO FOOD APPLICATION DURING THE COVID PANDEMIC 2021
}

\author{
Joelianti Dwi Supraptiningsih \\ STIE Pertiwi, Kota Bekasi Jawa Barat 17112, yuliantidwi6@gmail.com \\ Corresponding Author: First Author
}

\begin{abstract}
This study at to analyze the effect of product, price, place, and promotion on consumer purchasing decisions uses the Go Food application during the covid pandemic 2021 The research methodology used quantitative method with cross section data and primary data obtained from questionnaires. Mechanical sampling uses purposive sampling method. The data analysis technique used is multiple linear regression to test the validity, reliability test, normality test, classic assumption test (multicollinearity test, heteroscedasticity test) and hypothesis testing t-statistics and f-statistics to examine the effect together with a significance level of 5\%. The results of this study showed that in partial variables of Product, Price, Place, and Promotion have a positive impact and significant impact on consumer purchasing decisions using the Go Food application. Meanwhile, independent variables of Product, Price, Place, and Promotion simultaneously have a significant relationship to the dependent variables, on consumer purchasing decisions using the Go Food application. Coefficient of determination from this study shows $83.01 \%$. It shows that the variation of the independent variables are Product, Price, Place, and Promotion is able to explain the rise and fall of the dependent variable variation on consumer purchasing decisions using the Go Food application is $83.01 \%$, while the remaining of $16.99 \%$ is affected by other independent variables.
\end{abstract}

Keywords: Product, Price, Place, Promotion, Purchasing Decisions

\section{INTRODUCTION}

Talking about marketing strategy, at this time there have been big changes in the business world, especially modern marketing strategies. Media promotion is one thing that has undergone drastic changes. The closer the virtual world is to our daily lives, making the era 
of digitalization we cannot avoid. Along with the development of technology in cyberspace, which is supported by increasingly capable gadgets, the behavior of these people has also changed. Precisely since 2007 , many people use the internet as a place to get information. In the future, the number of people who depend on the internet as a source of information is increasing. So do not be surprised if print media such as newspapers have started to be abandoned, from this change that makes marketing strategies now shift to the online world (Maxmanroe, One way to win the market is through tactical planning. According to Shinta (2011), this tactical planning uses the concept of the marketing mix (Marketing Mix) which is a set of tactical marketing tools that can be controlled and combined by the company to produce the response desired by the target market. In mid-2010, the era of disruption in Indonesia began. Disruption is an innovation that will replace the entire old system in new ways. Disruption has the potential to replace old players with new ones. Disruption replaces old, all-physical technology with digital technology which produces something completely new and more efficient, also more useful (Kumparan, 2019).

With the proliferation of innovation developments in 2010, Gojek Indonesia was born. Gojek started its journey in 2010 with our first service, namely ordering motorcycle taxis through a call-center. In 2015, Gojek developed rapidly after launching an application with three services, namely: Go-Ride, Go-Send, and Go-Mart (Gojek Indonesia, 2020).

After launching three types of services, in the same year the premium motorcycle taxi service Gojek officially presented a food delivery service under the name Go-Food on April 1, 2015. Gojek itself claims that it cooperates with more than 15,000 restaurants spread throughout Jakarta. For culinary lovers, of course this is good news, considering that you no longer need to go far when you want to enjoy certain foods from restaurants or outlets that do not have food delivery services (id.techinasia, 2015).

Formulation of the problem

Based on the formulation of the problem above, the objectives of this study are as follows:

1. howEffect of Products on Consumer Purchase Decisions using the Go Food Application in Jakarta?.

2. howEffect of Price on Consumer Purchase Decisions using the Go Food Application in Jakarta?.

3. howEffect of Distribution on Consumer Purchase Decisions using the Go Food Application in Jakarta?.

4. howEffect of Promotion on Consumer Purchase Decisions using the Go Food Application in Jakarta?.

\section{THEORETICAL FRAMEWORK}

\section{a. Marketing Management}

In his book Kotler and Keller (2010:5), it is explained that the essence of marketing (marketing) is identifying and meeting human and social needs. One good and short definition of marketing is "satisfying needs in a profitable way". Marketing management occurs when at least one party to a potential exchange thinks about ways to achieve the response the other party wants. Because we view marketing management as the art and science of choosing target markets and reaching, retaining and growing customers by creating, delivering and communicating superior customer value. 


\section{b. Marketing Mix}

In Kartajaya and Darwin's book (2010: 116), it shows that the Marketing Mix itself is only one part of the nine marketing elements whose style is legacy, consisting of 3 strategic components (segmentation, targeting and positioning), 3 tactical components (differentiation, marketing-mix and selling), and 3 value components (brand, service and process).

\section{c. Consumer Decision}

In their book Kotler and Keller (2016: 192), purchasing decisions are explained as follows: "In the evaluation stage, the consumer forms preferences among the brands in the choice and may also form an intention to buy the most preferred brand". This means that in the evaluation stage, consumers form a choice among the preferred brands and can also form an intention to buy the most preferred brand.

\section{d. Product}

In their book, Mullins and Walker (2013: 252), defines a product as follows: "A product can be defined as anything that satisfies a wand or need through use, consumption or acquisition". Which means that a product can be defined as anything that satisfies a want or need through use, consumption or acquisition.

\section{e. Price}

Price is the only element of the marketing mix that generates sales revenue, while the other elements are just ordinary elements (Assauri, 2014: 233).

\section{f. Distribution}

Traditionally, this distribution channel is better known as a distributor. Its role can be just like a wholesaler or a combination of wholesaler and retailer. So, those whose name is distributors can only take goods from producers, they can also sell them to customers at the same time (Kartajaya and Darwin, 2010: 150).

\section{g. Promotion}

In his book Kotler and Armstrong (2015: 77), it is explained that promotion is as follows: "Promotion means activities that communicate the merits of the product and persuade target customers to buy it". By definition, promotion is an activity that communicates the advantages of a product and persuades consumers to buy the product.

\section{RESEARCH METHOD}

In his book Yusuf (2014: 24), which explains that research is a way to solve a problem or find answers to problems faced scientifically, using reflective thinking, scientific thinking with procedures that are in accordance with the objectives and nature of the investigation. . Scientific research uses systematic and controlled steps, is careful and logical, objective and empirical and directed at the target to be solved. The research carried out should be able to answer existing problems, express correctly or predict correctly. Where the type of research used in this study is a type of quantitative research (quantitative research). 
In his book Yusuf (2014: 145), it is explained that within the framework of research, especially quantitative research (quantitative research), population is one of the essential things and needs careful attention if researchers want to conclude a reliable and appropriate result for the area (area). ) or the object of research. The target population used by the author in compiling this research is a limited population, namely a population that can provide information to the author so that it can provide an overview of the conclusions in this study. The population that is the object of this research is the consumer of the Go Food application in Jakarta.

In simple terms it can be said that the sample is part of the selected population and represents the population. In determining the sample size, various statistical formulations can be used, so that the sample taken from the population actually meets the requirements for an acceptable level of confidence and the level of sample error that may be tolerated (Yusuf, 2014: 150). The sample used in this study uses the sample calculation method with the formula proposed by Slovin quoted in his book (Yusuf, 2014: 170), using a confidence level of $90 \%$ and of $10 \%$.

\section{DATA ANALYSIS AND DISCUSSION}

This researcher uses multiple regression analysis. Here is the regression equation:

$$
\mathrm{Y}=0+1 \mathrm{X} 1+2 \mathrm{X} 2+3 \mathrm{X} 3+4 \mathrm{X} 4+\mathrm{e}
$$

$$
\mathrm{Y}
$$

$0,1,2,3$

$\mathrm{X} 1$

$\mathrm{X} 2$

$\mathrm{X} 3$

$\mathrm{X} 4$

$\mathrm{e}$

$$
\text { = Decision Consumer Purchase }
$$

$$
=\text { Constant/Slope }
$$

$=$ Product

$=$ Price

$=$ Place

$=$ Promotion

$=$ Random error (error term)

\section{RESULTS AND DISCUSSION}

\section{a. Descriptive Statistics Test}

Table 1 Descriptive Statistics

\begin{tabular}{|c|c|c|c|c|c|}
\hline & $\begin{array}{c}\text { KEEP. } \\
\text { CONS. }\end{array}$ & $\begin{array}{c}\text { PRODU } \\
\text { CT }\end{array}$ & PRICE & DIST & $\begin{array}{c}\text { PROMO } \\
\text { TION }\end{array}$ \\
\hline mean & 13.30000 & 8.380000 & 11.77000 & 10.10000 & 10.98000 \\
\hline median & $\begin{array}{c}1400000 \\
0\end{array}$ & 8.000000 & $\begin{array}{c}12.00000 \\
0\end{array}$ & $\begin{array}{c}10,00000 \\
0\end{array}$ & $\begin{array}{c}12.00000 \\
0\end{array}$ \\
\hline Maximum & $\begin{array}{c}2000000 \\
0\end{array}$ & 16.00000 & 16.00000 & 16.00000 & 16.00000 \\
\hline Minimum & 6.000000 & 4000000 & 5.000000 & 5.000000 & 4000000 \\
\hline Std. Dev. & 3.289100 & 2.925955 & 2.809993 & 2.422537 & 3.031751 \\
\hline
\end{tabular}




\begin{tabular}{|l|r|r|r|r|r|}
\hline Skewness & 0.436694 & 0.625856 & 0.789903 & 0.096827 & $\begin{array}{c}- \\
0.573200\end{array}$ \\
\hline Kurtosis & 3.140391 & 3.487713 & 3.351219 & 3.601391 & 3.078395 \\
\hline $\begin{array}{l}\text { Jarque- } \\
\text { Bera }\end{array}$ & 3.260488 & 7.519361 & 10.91309 & 1.663218 & 5.501577 \\
\hline Probability & 0.195882 & 0.023291 & 0.004268 & 0.435348 & 0.063877 \\
\hline Sum & 1330,000 & 838.0000 & 1177,000 & 1010,000 & 1098.000 \\
\hline $\begin{array}{l}\text { Sum Sq. } \\
\text { Dev. }\end{array}$ & 1071,000 & 847.5600 & 781.7100 & $\begin{array}{c}581.0000 \\
0\end{array}$ & 909.9600 \\
\hline $\begin{array}{l}\text { Observatio } \\
\text { ns }\end{array}$ & 100 & & & & \\
\hline
\end{tabular}

Source: Edited by the Author, 2020

It can be concluded that the average value of Consumer Purchase Decisions using the Go Food Application from 100 respondents studied during the 2020 observation period is 13.30000. The highest value of Consumer Purchase Decisions using the Go Food Application is 20000000 and the lowest value of Consumer Purchase Decisions using the Go Food Application is 6.000000. The average product value of the 100 respondents studied during the 2020 observation period is 8.380000 . The highest product value is 16.00000 and the lowest product value is 4000000 . The average price value of the 100 respondents studied during the 2020 observation period is 11.77000 . The highest price value is 16.00000 and the lowest price value is 5.000000.The average distribution value of the 100 respondents studied during the 2020 observation period is 10.10000 . The highest distribution value is 16.00000 and the lowest distribution value is 5.000000. The average Promotion value of the 100 respondents studied during the 2020 observation period is 10.98000. The highest Promotional Value is16.00000 and the lowest Promotion value is 4000000.

\section{b. Validity Test}

Table 2 Validity Consumer Purchase Decisions variable test

\begin{tabular}{|c|c|c|c|c|c|}
\hline \multicolumn{7}{|c|}{ Validity test } \\
\hline & Q1 & Q2 & Q3 & Q4 & Q5 \\
\hline r count & 0.7528 & 0.7443 & 0.8247 & 0.7425 & 0.5524 \\
\hline r table & 0.1966 & 0.1966 & 0.1966 & 0.1966 & 0.1966 \\
\hline $\begin{array}{c}\text { r hit }>\text { r } \\
\text { table }\end{array}$ & Valid & Valid & Valid & Valid & Valid \\
\hline
\end{tabular}

Source: Data processed by the author, 2020

The results of the calculation of the validity of the 5 (five) statement items for the variable Consumer Purchase Decision appears to have a greater value of $r$ arithmetic $r$ table so that 
the 5 items of the statement of the variableConsumer Purchase Decisions using the Go Food Application declared Valid.

c. Reliability Test

Table 3 Reality Test

\begin{tabular}{|l|c|c|c|}
\hline \multicolumn{4}{|c|}{ Reality Test } \\
\cline { 2 - 4 } & $\begin{array}{c}\text { r } \\
\text { count }\end{array}$ & $\begin{array}{c}\text { Alpha } \\
\text { Cronbach }\end{array}$ & \\
\hline Product & 0.9961 & 0.8 & Very Reliable \\
\hline Price & 0.9961 & 0.8 & Very Reliable \\
\hline Distribution & 0.9961 & 0.8 & Very Reliable \\
\hline Promotion & 0.9961 & 0.8 & Very Reliable \\
\hline Consumer Decision & 0.9961 & 0.8 & Very Reliable \\
\hline
\end{tabular}

Source: Data processed by the author, 2020

The results of the calculation of the reliability of the 4 (four) instruments contained in the variables: Product, Price, Place, and Promotion on Consumer Purchase Decisions using the Go Food App appears to have a greater $r$ arithmetic value $r$ table so that the 4 instruments contained in the variables: Product, Price, Place, and Promotion on Consumer Purchase Decisions using the Go Food App in the questionnaire submitted, declared Reliable.

\section{d. Normality test}

\section{Table 4 Normality Test}
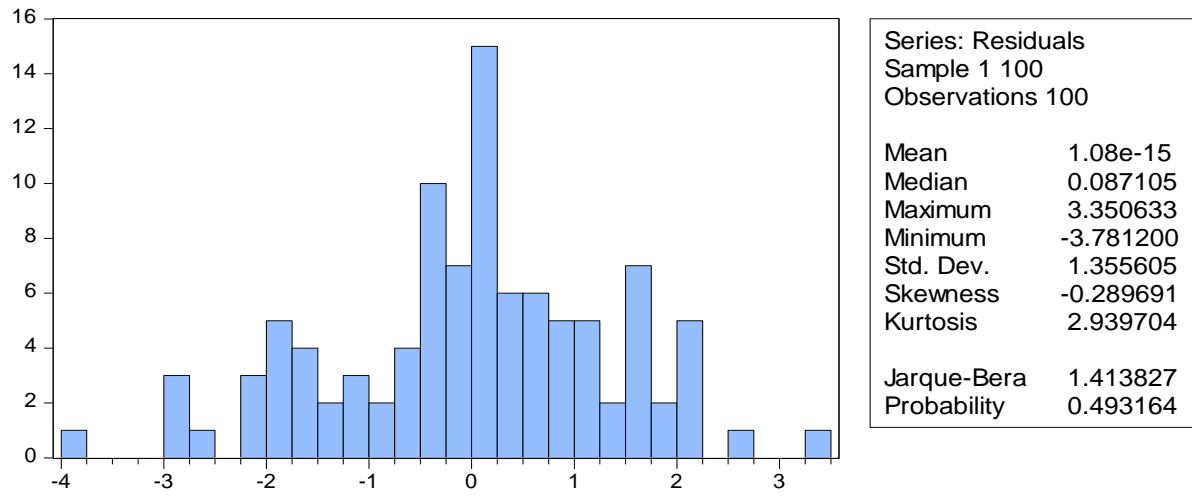

Source: Eviews 7 data processing results, 2020

Based on these results, it appears that the statistical value of the Jarque - Bera test is JB $(1.413827)<\mathrm{X} 2(11.070)$ or $\mathrm{p}$-value $(0.493164)>(0.05)$, then the null hypothesis fails to be rejected, which means that the residuals from the research model are normally distributed so that the $\mathrm{t}$-test and $\mathrm{F}$ test can be done to see the significance of the model.

\section{CLASSIC ASSUMPTION TEST RESULTS}

\section{a. Multicollinearity Test}


Table 5 Multicollinearity Test

\begin{tabular}{|c|c|c|c|c|}
\hline & Product & Price & $\begin{array}{c}\text { Distribut } \\
\text { ion }\end{array}$ & $\begin{array}{c}\text { Promoti } \\
\text { on }\end{array}$ \\
\hline & 1.00000 & 0.55252 & 0.77550 & 0.50074 \\
Product & 00 & 7 & 6 & 8 \\
\hline & 0.55252 & 1.00000 & 0.66224 & 0.54723 \\
Price & 7 & 00 & 1 & 7 \\
\hline Distribu & 0.77550 & 0.66224 & 1.00000 & 0.61779 \\
tion & 6 & 1 & 00 & 0 \\
\hline Promoti & 0.50074 & 0.54723 & 0.61779 & 1.00000 \\
on & 8 & 7 & 0 & 00 \\
\hline
\end{tabular}

Source: Eviews 7 data processing results, 2020

From the results of the correlation coefficient test between independent variables, there is no multicollinearity between the independent variables Product, Price, Place, and Promotion. Where the correlation value between the independent variables Product, Price, Place, and Promotion is below 0.85 .

\section{b. Heteroscedasticity Test}

Table 6Heteroscedasticity Test

Heteroskedasticity Test: Glejser

\begin{tabular}{lrlr}
\hline \hline & 3.8089 & & 0.006 \\
F-statistics & 86 & Prob. F(4.95) & 5 \\
& 13.821 & & 0.007 \\
Obs*R-squared & 21 & Prob. Chi-Square(4) & 9 \\
Scaled & 14.570 & & 0.005 \\
explained SS & 10 & Prob. Chi-Square(4) & 7 \\
\hline \hline
\end{tabular}

Source: Eviews 7 data processing results, 2020

From the results of the Glejser test, it can be seen that there is a heteroscedasticity problem in the observations in this study. This can be seen in the probability value of Chi Square $(0.0079)<=5 \%(0.05)$.

With the heteroscedasticity problem thenHeteroscedasticity healing needs to be done using the HAC standard errors and covariance method developed by Newey White and Kenneth contained in the Eviews 7.0 program.

\section{c. Heteroscedasticity Problem Healing}

Table 7 Heteroscedasticity Problem Healing 


\begin{tabular}{crcrr} 
& Coeffic & & t- \\
Variable & ient & Std. Error & Statistic & Prob. \\
\hline \hline & - & & - & \\
$\mathrm{C}$ & 0.1679 & & 0.37539 & 0.708 \\
& 78 & 0.447474 & 1 & 2 \\
PRODUCT & 0.2353 & & 2.34596 & 0.021 \\
& 20 & 0.100309 & 1 & 1 \\
PRICE & 0.4682 & & 5.16622 & 0.000 \\
DISTRIBUTIO & 0.4357 & 0.090630 & 9 & 0 \\
$\mathrm{~N}$ & 49 & 0.106750 & 4.08195 & 0.000 \\
& 0.1442 & & 2 & 1 \\
PROMOTION & 68 & 0.059390 & 1 & 0 \\
\hline \hline
\end{tabular}

Source: Eviews 7 data processing results, 2020

Heteroscedasticity problem has been cured using the HAC Standard Errors \& Covariance method. Where the Standard Errors, t-Statistic, and Probability values have changed.

\section{HYPOTHESIS TEST RESULTS}

a. Hypothesis Test (Partial t)

\section{Table 7 Hypothesis Testing (Partial t)}

\begin{tabular}{|c|c|c|c|c|}
\hline Variable & $\begin{array}{r}\text { Coeffic } \\
\text { ient }\end{array}$ & Std. Error & $\begin{array}{r}{ }^{\mathrm{t}}- \\
\text { Statistic }\end{array}$ & Prob \\
\hline & - & & - & \\
\hline & 0.1679 & & 0.37539 & 0.708 \\
\hline \multirow[t]{2}{*}{$\mathrm{C}$} & 78 & 0.447474 & 1 & 2 \\
\hline & 0.2353 & & 2.34596 & 0.021 \\
\hline \multirow[t]{2}{*}{ PRODUCT } & 20 & 0.100309 & 1 & 1 \\
\hline & 0.4682 & & 5.16622 & 0.000 \\
\hline PRICE & 13 & 0.090630 & 9 & 0 \\
\hline DISTRIBUTIO & 0.4357 & & 4.08195 & 0.000 \\
\hline \multirow[t]{2}{*}{$\mathrm{N}$} & 49 & 0.106750 & 2 & 1 \\
\hline & 0.1442 & & 2.42915 & 0.017 \\
\hline PROMOTION & 68 & 0.059390 & 1 & c \\
\hline
\end{tabular}

Source: Eviews 7 data processing results, 2020

1. The value of tcount (2.345961) > ttable (1.98525), which means rejecting $\mathrm{H} 0$ and accepting H1. So that the first hypothesis proposed states that there areinfluence Producton Consumer Purchase Decisionsuse Go Food App in Jakarta, acceptable. 
2. Score tcount (5.166229) $>$ ttable (1.98525), which means rejecting H0 and accepting H1. So the second hypothesis proposed states that there arePrice influence on Consumer Purchase Decisionsuse Go Food App in Jakarta, acceptable.

3. Score tcount (4.081952) > table (1.98525), which means rejecting $\mathrm{H} 0$ and accepting H1. So that the third hypothesis proposed states that there areDistribution influence on Consumer Purchase Decisionsuse Go Food App in Jakarta, acceptable.

4. The value of tcount (2.429151) > ttable (1.98525), which means rejecting $\mathrm{H} 0$ and accepting H1. So that the fourth hypothesis proposed states that there arePromotion influence on Consumer Purchase Decisionsuse Go Food App in Jakarta, acceptable.

\section{b. Hypothesis Testing (Simultaneous f)}

Table 8 Hypothesis Testing (Simultaneous f)

\begin{tabular}{lr}
\hline \hline & 116.06 \\
F-statistics & 43 \\
& 0.0000 \\
Prob(F-statistic) & 00 \\
\hline \hline
\end{tabular}

Source: Eviews 7 data processing results, 2020

DFrom the results of these calculations, it is known that based on Ftable with $\mathrm{df}=4.95$ with $=5 \%$, the Ftable value is 2.47. So it can be concluded that Fcount (116.0643) > Ftable (2.47), which means rejecting $\mathrm{H} 0$ and accepting $\mathrm{H} 1$. So the fourth hypothesis proposed is that there are

influence Product, Price, Distribution, and Promotiontogether on Consumer Purchase Decisions using the Go Food Application in Jakarta, acceptable.

\section{c. Coefficient of Determination}

Table 9 Coefficient of Determination (R2)

\begin{tabular}{lr}
\hline \hline & 0.8301 \\
R-squared & 32 \\
Adjusted R- & 0.8229 \\
squared & 79 \\
\hline \hline
\end{tabular}

Source: Eviews 7 data processing results, 2020

From the results of these calculations, the magnitude of the influence of the independent variable on the dependent variable which can be explained by the model in this equation is 0.830132 or $83.01 \%$. This shows that the variation of the Product, Price, Distribution, and Promotion variables is able to explain the variation of the increase/decrease in Consumer Purchase Decisions.use The Go Food application is $83.01 \%$ while the remaining $16.99 \%$ is explained by variables other than Product, Price, Distribution, and Promotion which are not included in this regression model. 


\section{CONCLUSIONS AND SUGGESTIONS \\ Conclusion}

Based on the calculation of multiple linear regression analysis, it can be concluded as follows:

a. Product Influence Analysis on Consumer Purchase Decisions using the Go Food Application in Jakarta

The product variable partially has a positive correlation coefficient value and has a significant effect on consumer purchasing decisions using the Go Food application in Jakarta of 0.235320 . While the results of the calculation of the $t$ test for the Product variable, where tcount (2.345961) > ttable (1.98525). This is because the Go Food application has a variety of menu options and with various merchants so that users or consumers can choose what food and drinks they want. Next, the food and beverage products offered in the Go Food application range from Indonesian specialties to foreign specialties. The food and drinks offered are well packaged and maintained in quality. Furthermore, the products offered by Go Food are in accordance with the images listed in the Go Food application for users or consumers so as to minimize errors in ordering food or drinks.

b. Analysis of the Effect of Price on Consumer Purchase Decisions using the Go Food Application in Jakarta

The price variable partially has a positive correlation coefficient value and has a significant effect on Consumer Purchase Decisions using the Go Food Application in Jakarta of 0.468213 . While the results of the t-test calculation for the price variable, where tcount (5.166229) > ttable (1.98525).This is because the price offered by the Go Food application for the food and beverage menu is in accordance with the quality of the product so that this condition makes consumers decide to use the Go Food application. Furthermore, the prices for each menu of food or beverage choices are very affordable for consumers and Go Food always holds promo vouchers contained in the consumer Go Food application that can be used to get discounts. Meanwhile, in terms of price and the number of restaurants that cooperate, Go Food has a competitive price comparison with similar applications issued by competitors such as the Grab Food application.

c. Analysis of the Effect of Distribution on Consumer Purchase Decisions using the Go Food Application in Jakarta

The distribution variable partially has a positive correlation coefficient value and has a significant effect on Consumer Purchase Decisions using the Go Food Application in Jakarta of 0.435749 . While the results of the calculation of the $t$ test for the distribution variable, where tcount (4.081952) > ttable (1.98525). This is because the Go Food service has a very wide scope and works with various merchants, ranging from international franchise outlets to culinary Micro, Small and Medium Enterprises (MSMEs) which are already widely available in the DKI Jakarta area. Go Food has sophisticated technology in the form of applications that make it easier for users or consumers to choose various kinds of food or drinks that are available in one hand. With sophisticated technology and easy to use, this is what makes the Go Food application very easy to access by users or consumers wherever they are. With Go Food, users or consumers do not need to spend time queuing at restaurants. 


\section{d. Analysis of the Effect of Promotion on Consumer Purchase Decisions using the Go Food Application in Jakarta}

Promotional variable partially has a positive correlation coefficient value and has a significant effect on Consumer Purchase Decisions using the Go Food Application in Jakarta of 0.144268 . While the results of the t-test calculation for the Promotion variable, where tcount (2.429151) > ttable (1.98525). This is because the promotions carried out by Go Food always prioritize information about food and beverages properly and clearly to consumers. Then Go Food also always communicates information about food and beverages that are easily understood by consumers so as to minimize errors before food or drinks reach the hands of consumers. In addition, Go Food carries out promotions in various media, namely using electronic advertising media, billboards, social media such as Instagram, Twitter,

2. Suggestion

Based on these conclusions, several suggestions can be made. The suggestions given are as follows:

a. For the community, the results of this study are expected to be useful to increase public knowledge, especially Go Food application users.

b. For the Company, this research illustrates that Product, Price, Place, and Promotion have a significant influence on the use of the Go Food Application by consumers. Where the development of the Ride Hailing concept in Indonesia, which was popularized, needs to be maintained and improved even though the assessment of the author's questionnaire results is very good.

c. For the author, this research provides new knowledge for me and is more aware that the influence of Product, Price, Place, and Promotion affects consumer purchasing decisions.

d. For further researchers, it is hoped that this research can be used as a reference or as an example and can be developed further so that other findings can be obtained for the development of science, especially Marketing Science.

\section{BIBLIOGRAPHY}

Abdullah, Thamrin dan Francis Tantri. 2016. Manajemen Pemasaran. Penerbit PT. RajaGrafindo Persada. Depok.

Abdurrahman, Nana Herdiana. 2015. Manajemen Strategi Pemasaran. Penerbit CV. Pustaka Setia. Bandung.

Ariefianto, Mochamad Doddy. 2012. Ekonometrika : Esensi dan Aplikasi dengan menggunakan Eviews. Penerbit Erlangga. Jakarta.

Assauri, Sofjan. 2014. Manajemen Pemasaran. Penerbit PT. RajaGrafindo Persada (Rajawali Press). Jakarta.

Daft, Richard L. 2010. New Era Of Management. Penerbit Salemba Empat. Jakarta.

Fayol, Henry. 2010. Manajemen Public Relations. Penerbit PT. Elex Media. Jakarta.

Hermawan, Agus. 2012. Komunikasi Pemasaran. Penerbit Erlangga. Jakarta.

Hersey, Paul dan Blanchard, Kenneth H. 2013. Manajemen Perilaku Organisasi. Terhemahan Agus Dharma. Penerbit Erlangga. Jakarta.

Kartajaya, Hermawan. 2010. The Official MIM Academy Coursebook: Brand Operation. Penerbit Erlangga. Jakarta. 
Kartajaya, Hermawan dan Waizly Darwin. 2010. Connect! Surfing New Wave Marketing. Penerbit PT. Gramedia Pustaka Utama. Jakarta.

Kotler, Philip dan Keller, Kevin Lane. 2010. Manjemen Pemasaran. Penerbit Erlangga. Jakarta. Edisi Ke-13 Jilid 1.

Kotler, Philip dan Keller, Kevin Lane. 2012. Marketing Management. Penerbit Pearson International Edition, New Jersey. 14th Edition.

Kotler, Philip dan Armstrong, Gary. 2015. Principle of Marketing. Penerbit Prentice-Hall. New Jersey. 15th Edition.

Kotler, Philip dan Keller, Kevin Lane. 2016. Marketing Management. Penerbit Pearson Education Inc. Edinburgh Gate Harlow. 15th Global Edition.

Lupiyoadi, Rambat dan A. Hamdani. 2011. Manajemen Pemasaran Jasa. Penerbit Salemba Empat. Jakarta. Edisi Kedua.

Mullins, John W. dan Walker Jr, Orville C. 2013. Marketing Management: A Strategic DecisionMaking Approach. Penerbit McGraw-Hill International Edition. New York. 8th Edition.

Natakusumah, Fiera Aryati dan Ai Lili Yulianti. 2016. PENGARUH BAURAN PEMASARAN TERHADAP KEPUTUSAN PEMBELIAN (Studi Pada Ina Cookies Bandung). Jurnal Manajemen Teori dan Terapan. Tahun 9 Nomor 1. Bandung.

Nugroho, Juli Setiadi. 2013. Perilaku Konsumen: Perspektif Kontemporer pada Motif, Tujuan, dan Keinginan Konsumen. Penerbit Kencana Prenada Media Group. Jakarta. Edisi Revisi.

Pertiwi, Marina Intan. Edy Yulianto., dan Sunarti. 2016. PENGARUH BAURAN PEMASARAN TERHADAP KEPUTUSAN PEMBELIAN (Survei pada Konsumen Baker's King Donuts \& Coffee di MX Mall Malang). Jurnal Administrasi Bisnis (JAB). Volume 37 Nomor 1. Malang.

Prenzel, Immo. 2010. Applicability of Mobile Marketing in the Marketing Mix of Trade Fair Organizers. Penerbit Diplomica Verlag GmbH. Hamburg.

Robbins, Stephen P. dan Coulter, Mary. 2010. Manajemen. Penerbit Erlangga. Jakarta. Edisi Kesepuluh.

Solomon, Michael R. 2015. Consumer Behavior: Buying, Having and Being. Penerbit Prentice-Hall. New Jersey. 11th Edition.

Stoner, James A. F. dan Wankel, Charles. 2013. Pengantar Manajemen. Dialih bahasakan oleh H.B. Siswanto. Penerbit Bumi Aksara. Jakarta. Edisi Keempat Jilid Lima.

Sugiarto. 2017. Metodologi Penelitian Bisnis. Penerbit Andi. Yogyakarta.

Sugiyono. 2016. Metode Penelitian Kuantitatif, Kualitatif dan R\&D. Penerbit Alfabeta. Bandung.

Sukarna. 2011. Dasar-Dasar Manajemen. CV. Mandar Maju. Bandung

Sutrsino, Novelia Al-Raafi Rizki Adinda. Joko Widodo., dan Zulianto, Mukhamad. 2018. PENGARUH BAURAN PEMASARAN TERHADAP KEPUTUSAN PEMBELIAN PRODUK RM AYAM BAKAR WONG SOLO. Jurnal Pendidikan Ekonomi: Jurnal Ilmiah Ilmu Pendidikan, Ilmu Ekonomi, dan Ilmu Sosial. Volume 12 Nomor 2. Jember.

Sule, Ernie Tisnawati dan Kurniawan Saefullah. 2010. Pengantar Manajemen. Penerbit Prenada Media Kencana. Jakarta.

Tjiptono, Fandy. 2015. Strategi Pemasaran. Penerbit Andi. Yogyakarta.

Tjiptono, Fandy dan Anastasia Diana. 2016. Pemasaran: Esensi dan Aplikasi. Penerbit Andi. Yogyakarta. 
Tumbel, Altje Lenny dan Paulina Van Rate. 2015. PENGARUH BAURAN PEMASARAN TERHADAP KEPUTUSAN PEMBELIAN DI PASAR TRADISIONAL (Studi Pada Pasar Tradisional di Kota Manado). Jurnal LPPM Bidang EkoSosBudKum Volume 2 Nomor 2. Manado.

Widarjono, Agus. 2013. Ekonometrika : Pengantar dan Aplikasinya Disertai Panduan Eviews. Penerbit UPP STIM YKPN. Yogyakarta. Edisi Keempat.

Yusuf, A. Muri. 2014. Metode Penelitian Kuantitatif Kualitatif dan Penelitian Gabungan. Penerbit Prenada Media. Jakarta.

www.cnbcindonesia.com/tech/20200310095833-37-143677/ini-daftar-lengkap-kenaikan-tarif-ojolberlaku-16-maret (Diakses 11 Januari 2020)

www.cnbcindonesia.com/tech/20190923131149-37-101425/gofood-kuasai-75-pangsa-pasarindonesia (Diakses 11 Januari 2020)

www.cnbcindonesia.com/tech/20190404151911-37-64657/perjalanan-gojek-karya-anak-bangsasabet-gelar-decacorn (Diakses 11 Januari 2020)

www.cnnindonesia.com/teknologi/20190218014809-185-370201/mengenal-istilah-unicorn-dalamdunia-startup (Diakses 11 Januari 2020)

www.databoks.katadata.co.id/datapublish/2019/01/04/jumlah-penduduk-indonesia-2019-mencapai-267juta-jiwa (Diakses 11 Januari 2020)

www.gojek.com/about/ (Diakses 11 Januari 2020)

www.google.com/amp/s/m.kumparan.com/amp/temali/memasuki-era-disrupsi-dan-menghadapinya1rP1bBzWuG5 (Diakses 11 Januari 2020)

www.google.com/amp/s/markey.id/blog/bisnis/gojek-indonesia/amp (Diakses 11 Januari 2020)

www.id.techinasia.com/gofood-gojek-layanan-delivery-makanan (Diakses 11 Januari 2020)

www.id.techinasia.com/talk/apa-itu-bisnis-startup-dan-bagaimana-perkembangannya (Diakses Januari 2020)

www.maxmanroe.com/strategi-pemasaran-modern.html (Diakses 11 Januari 2020)

www.maxmanroe.com/pengertian-marketing-mix.html (Diakses 11 Januari 2020)

www.markey.id/blog/bisnis/gojek-indonesia/amp (Diakses 11 Januari 2020)

www.cnbcindonesia.com/tech/20200316061757-37-145021/hari-ini-tarif-baru-grab-gojek-cs-berlakunaik-rp-250-km (Diakses 11 Januari 2020) 